Јована Д. Јоковић ${ }^{1}$

Универзитет у Београду, Факултет за специјалну едукацију и рехабилитацију

\title{
Стручни рад
}

\section{Ризици вирӣууелної свет̄а за млаgе и иревенција зависносйи оg инйернетиа}

Резиме: У gанашне време уобичајено је gа су информационо-комуникачионе иехеноло-

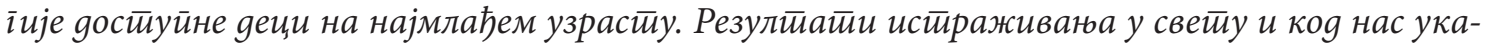

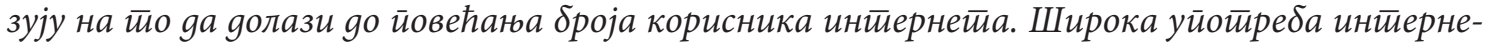
йа йочиюе gевеgесеитих іолина и веома брзо йостиаје незамислива база информачија, нових начина комуникачије, gрушитвених мрежа и слично. Као и сваки gруіи меgиј gо саgа и ин-

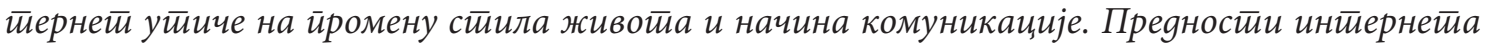

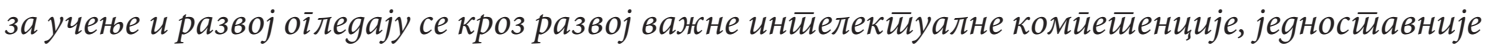

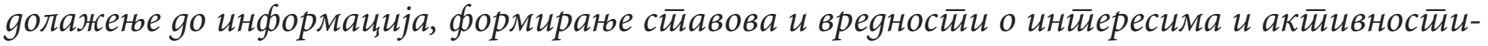
ма које их йовезују, брзу и лаку комуникацију, занимљивији начин учеюь, као и йоgсиициағе

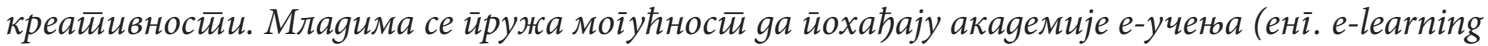

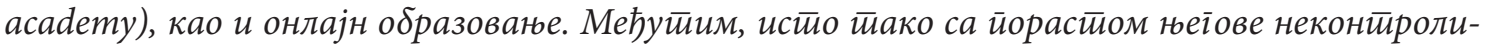

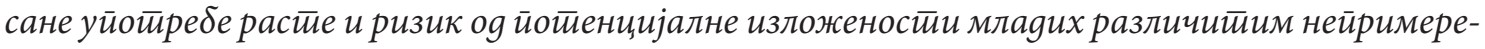
ним саяржајима, злоуйоиребама и искоришћаваюу. Како се иовећава време које деия йровоgе

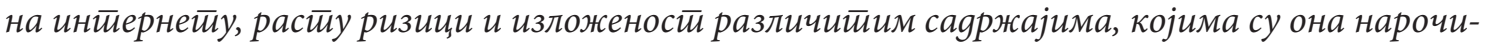

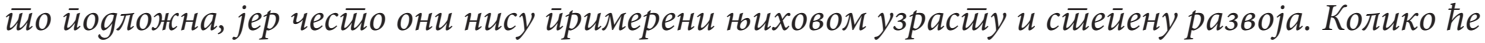

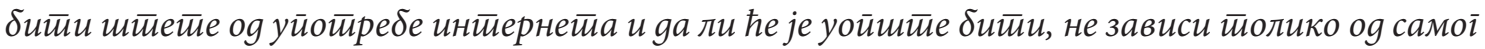

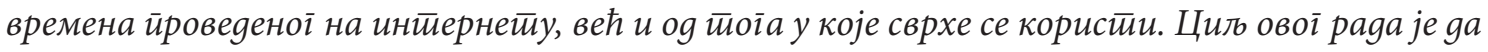
се на основу ирреіллеgа и анализе досииуйне релеванитне литерайуре саїлеgају йойенцијални

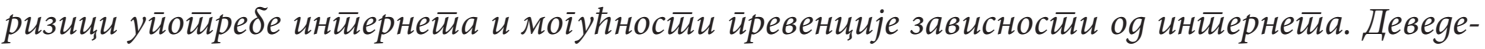

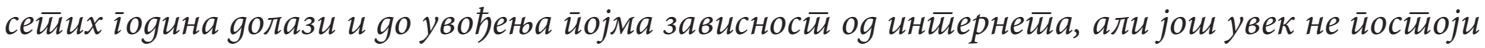
сайласности у вези са йризнаваюем овоі йојма, йермина и еиииолоїије, као ни око најбольеі ме-

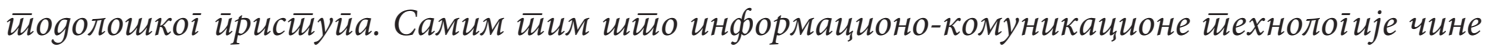

$\overline{1 \text { jjokovic94@gmail.com }}$ Copyright $\odot 2018$ by the authors, licensee Teacher Education Faculty University of Belgrade, SERBIA.

This is an open access article distributed under the terms of the Creative Commons Attribution License (CC BY 4.0) (https://creativecommons.org/licenses/by/4.0/), which permits unrestricted use, distribution, and reproduction in any medium, provided the original paper is accurately cited. 


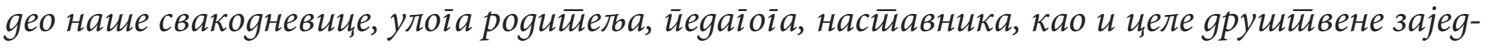
нице йостиаје сложенија.

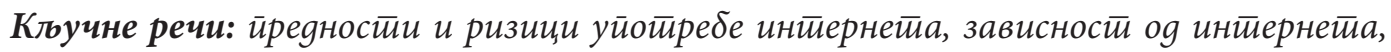
йревенција, млаgи, медијска иисмености.

Увод

У данашње време масовна средства комуникације доступна су и најмлађем узрасту. Последњих деценија долази до повећања броја корисника интернета, што показују бројна истраживања рађена у свету и код нас. Наиме, неконтролисана употреба интернета, посебно повезана са радозналошћу деце и њиховом жељом за забавом и разонодом, носи са собом бројне потенцијалне ризике.

Нове технологије су саставни део живота и имају многобројне могућности за учење и развој, али са собом носе и многе потенцијалне ризике, посебно за децу и младе, који још увек немају развијену способност процене ризика и доношења одлука. Широка и јавна употреба интернета почиње деведесетих година, и веома брзо постао је незамислива база информација, музике, филмова, књига, нових начина комуникације, друштвених мрежа и слично. Интернет утиче на промену стила живота и начина комуникације и тако потврђује тезу да сваки нови медиј мења људску свест. Деца и млади користе интернет за учење, комуникацију, социјалну интеракцију са пријатељима и за игру и забаву. Они су подложни многим опасностима на интернету као што су: неадекватни садржаји, слике, вршњачко насиље, порнографија, крађа података и слично. Улога родитеља, наставника, педагога, као и друштвене заједнице, постаје много сложенија, самим тим што информационо-комуникационе технологије чине део наше свакодневице.

Деведесетих година, такође, долази до увођења појма зависност од интернета. Ова појава описује се путем различитих опсесивнокомпулсивних поремећаја, патолошке употре- бе интернета и слично. Још увек не постоји сагласност у вези са признавањем овог појма, око термина, етиологије зависности и око најбољег методолошког приступа. Такође, још увек не постоји сагласност око тога где су границе нормалног, односно прекомерног коришћења интернета. У овом раду посветићемо пажњу карактеристикама интернета, замкама и ризицима којима могу бити изложени деца и млади, као и појму зависности од интернета и могућностима њене превенције. Указаћемо и на важност медија, односно медијске писмености чија је суштина да кориснике упозна са ризицима које носе медији, али и са њиховим могућностима. Зато је веома важан педагошки однос према медијима, односно медијско образовање.

\section{Развој и карактеристике интернета}

Последњих неколико година сведоци смо повећања употребе дигиталних технологија и интернета, посебно међу децом и младима. Према речима неких аутора, интернет је настао 1969. године и дефинише се као „глобални комуникациони систем међусобно повезаних компјутерских мрежа намењен размени информација“" (Radovanović, Spasić, 2009: 243).

Други аутори (Popadić, Kuzmanović, 2016) истичу да је почетак деведесетих година донео праву револуционарну новину, а то је интернет. Мада се његов проналазак смешта у 1969. годину, широка и јавна употреба почела је почетком деведесетих година 20. века. Постао је незамислива база моментално доступних информација, музике, филмова, књига, медијум за међусобну комуникацију, слање порука бесконачно великој публици, „качење“ омиљених садржаја, власти- 
тих идеја, коментара, реаговања на туђе поруке. Као посебно популарно међу младима јесу онлајн социјалне мреже. Корисници имају могућност да креирају свој профил, представе себе на велики број начина, буду у контакту са другима и учествују у интеракционој мрежи.

Ауторке Радовановић и Спасић (Radovanović, Spasić, 2009) наводе да се интернет у Србији почиње развијати од фебруара 1996. године, када је национална академска мрежа преко провајдера BeoTelNet-a спојена на интернет. Деведесетих година човечанство је било фасцинирано интернетом. Развој интернета, повећање броја корисника и интернет апликација неочекивано брзо превазишли су сва очекивања. У последње две деценије интернет је успео више него иједно друго савремено технолошко откриће. Олакшао је живот човека, тако да је данас немогуће замислити свакодневни живот и рад без интернета, без обзира на то да ли је реч о послу, комуникацији или забави. На интернету, за разлику од реалног живота, скоро да не постоје границе. Постоји могућност приступа обиљу података, куповини, рекламирању, забави, музици, филмовима, могуће је пронаћи људе расположене за разговор, размену информација. Исте ауторке, такође, истичу да интернет више, брже и лакше него било који други медиј задовољава потребу човека као социјалног бића за комуникацијом и друштвом, пружа осећај припадања и прихватања без обзира на расу, пол, мане или старост.

Даље, многи сматрају да је интернет комуникацијски догађај који је утицао на промену стила живота и начина комуникације и тако потврдио тезу да сваки нови медиј мења људску свест. Повећава се брзина протока информација, повећан је број могућих форми комуницирања, али и брзина застаревања информација. Деца су његови главни корисници и сајберкритичари их сматрају новом комуникацијском генерацијом (Zgrabljić Rotar, 2005).
Попадић и Кузмановић (Popadić, Kuzmanović, 2016) наводе да се за непуне две деценије драстично изменила комуникациона пракса међу људима. Одраслима је остало да се привикавају брзим променама, а деци и младима је свет у којем доминирају дигитални медији једини свет који познају, а дигитална комуникација њихов матерњи језик. Други аутори (Vrućinić, Rodić, 2016), такође, истичу да је интернет постао део свакодневног живота у савременом друштву и да је са собом донео многе предности. Омогућио је људима да несметано комуницирају једни са другима без обзира на међусобну удаљеност, олакшао је многе послове, куповину, плаћање, похађање разних курсева, трансакције и слично.

Интернет подразумева интерактивност у комуникацији и за многе пружа нови свет отворене комуникације који је растерећен моралних дилема културног наслеђа цивилизованог света. Иако умногоме доприноси развоју свих сфера друштвеног живота од образовања, политике, запослења, забаве, са друге стране, виртуелна култура отвара простор за многе злоупотребе (Lepojević-Kovačević, 2011).

Недуго после самог развоја масовне употребе интернета почињу се примећивати и неки негативни утицаји. Све је израженија потреба за дужим боравком на интернету. Први пут се 1995. године помиње облик зависности у оригиналу назван Internet Addiction Disorder - IAD. Код

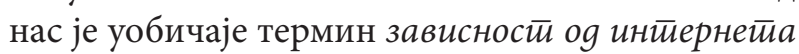
(Radovanović, Spasić, 2009).

\section{Предности и ризици употребе интернета}

Како смо већ навели, интернет је постао део свакодневног живота. Умногоме је олакшао живот савременом човеку, али осим његових предности постоји и велики број опасности, којима су посебно изложене деца и млади. Одрасли, млади и деца препуштају се новом иза- 
зову, без страха и не схватајући могуће ризике и последице неадекватног и небезбедног коришћења интернета (Rajić, 2012: 70). Како се повећава време које корисници проводе на интернету, расту и ризици и изложеност деце различитим садржајима.

За децу је данас уобичајено да користе интернет као да се играју са омиљеном играчком. Деца и млади користе интернет за учење, комуникацију, социјалну интеракцију са пријатељима и за игру и забаву. Међутим, како још увек немају довољно развијену способност процене ризика и доношења одлука, посебно су подложни многим опасностима на интернету, као што су: излагање неадекватним сликама и садржајима, успостављање комуникације са сексуалним предаторима, вршњачко насиље, неприкладно разоткривање личних информација, крађа података и слично (Vrućinić, Rodić, 2016).

Све већу присутност деце на интернету потврђују и резултати истраживања спроведеног 2010. године у ОШ „Бановић Страхиња“ у Београду, на узорку од сто ученика четвртог разреда. У погледу обима коришћења интернета резултати нам показују да мање од једне половине интернет користи свакодневно (Rajić, 2012).

Ауторка Роботић (Robotić, 2015) истиче да уз многе предности и занимљив начин учења интернет представља и велики ризик за децу и младе. Данашња деца и млади одрастају и живе другачије него што су живели њихови родитељи и знају много више о електронским медијима, чиме родитељска улога постаје још сложенија. Данас је немогуће да дете одраста без компјутера и осталих информационо-комуникационих технологија које чине део наше свакодневице. Оне, свакако, омогућавају деци и младима забаву и могућности за учење и комуницирање. Посебно су подложни утицају млади који одрастају уз телевизију, компјутере и мобилне телефоне, такозвана gиіийална или нети іенерација. Док су генерације до сада користиле технологију у своје слободно време, данашње генерације их употребљавају континуирано као начин живота. Од малих ногу поседују одличну информатичку писменост и много се боље разумеју у савремену технологију од родитеља. Са порастом дечјег одушевљења технологијом расте забринутост родитеља, којима је потребна подршка и едукација о томе како да се носе са овим изазовима.

Већ смо споменули да су за последње две деценије дигиталне технологије постале свакодневица људи широм планете. Неки аутори (Popadić, Kuzmanović, 2016) наводе да су дигитални медији постали најраспрострањенији и најмоћнији медији. Међу корисницима интернета налази се једна трећина оних који су млађи од осамнаест година.

Многи аутори који се баве овом области истичу предности али и ризике употребе интернета када су у питању деца и млади. Ауторка Роботић (Robotić, 2015: 82) тако истиче бројне позитивне стране интернета:

- брза и лака доступност информација;

- мотивација за учење;

- извор забаве;

- омогућује брзу и лаку комуникацију без обзира на то где се налазимо;

- омогућује размену искустава, мишљења и информација;

- побољшавају се вештине писања деце и младих и подстиче развој креативности;

- подстиче развој стратегија решавања проблема и селекције информација.

Иста ауторка даље истиче да нам је интернет омогућио едукацију, комуникацију и забаву и све то у исто време. Такође, омогућује нам да упознајемо друге људе и културе, да путујемо, купујемо, покажемо своја знања и таленте људима широм света. Путем интернета могу се пружити утеха и помоћ у тешким тренуцима или поделити радост у тренуцима среће и разменити искуства. Велике су предности интернета и 
сваким даном све више расту. Можемо га назвати најмоћнијим образовним и комуникацијским медијем у историји света, према речима поменуте ауторке.

Поред наведених предности интернет скрива и многе опасности. Као главни ризици употребе интернета међу децом у литератури се наводе излагање сексуалним и насилним садржајима, директна комуникација са особама које траже непримерене односе, као и изложеност непристојним електронским порукама (Rajić, 2012: 72). Један од ризика дуготрајног коришћења интернета је социјална изолованост, која може водити у интернет зависност (Robotić, 2015). Такође, ту су и опасности од приступа непримереним садржајима (порнографија, крваве и насилне сцене, подстицање на уживање дроге и слично), али и странице на којима се продају забрањени производи, које не штите приватност деце и где деца могу објавити важне податке и тиме бити изложена крађи идентитета, преварама, као и многе друге опасности.

Зуковић и Слијепчевић (Zuković, Slijepčević, 2015) истичу, осим вредности и образовног потенцијала интернета, који још увек није искоришћен довољно, чињеницу да се у јавности све више говори о опасностима и ризицима употребе интернета које је могуће поделити у три категорије:

- ризичан садржај (провокативан садржај, дезинформисање);

- ризичан контакт (контакт ван мреже, умрежени контакт - сексуално узнемиравање, нарушавање приватности, сајбермалтретирање);

- - комерцијални ризик (комерцијална експлоатација, нежељено узимање личних података).

Једно занимљиво истраживање које је радио Уницеф (UNICEF, 2016) указује на две доминантне области, које, по процени родитеља, у највећој мери заокупљају пажњу деце на интер- нету, а то су: забава и разонода (играње игрица и музички садржаји) и комуникација на друштвеним мрежама са вршњацима. Друштвене мреже и комуникација са вршњацима постаје интернет преокупација на узрасту од дванаест година, а на узрасту од четрнаест до седамнаест за 70\% деце те генерације је свакодневна интернет активност. Када су у питању учење и образовање, истраживање показује да нису активности које доминирају међу децом, иако 60\% деце користи неколико пута недељно интернет за учење, учесталост ове активности није изражена у довољној мери.

Резултати поменутог истраживања, спроведеног у ОШ „Бановић Страхиња“, такође указују да, у погледу сврхе коришћења интернета, ученици четвртог разреда у највећем проценту на интернету играју игрице. Осим што играју игрице и користе интернет у образовне сврхе, ученици највише времена проводе на друштвеним мрежама (Rajić, 2012: 76).

\section{Појам и облици зависности од интернета}

Постоје несугласице везане за дефинисање проблематичне употребе интернета. Најчешћи називи су: „зависност од интернета, проблематична употреба интернета, компулсивна употреба интернета, патолошка употреба интернета" (Vrućinić, Rodić, 2016: 68). Ауторка Ковачевић-Лепојевић (Kovačević-Lepojević, 2011) истиче да се у научним круговима воде расправе о прикладној дефиницији понашања које одражава негативну, прекомерну, нефункционалну, проблематичну, компулсивну употребу интернета. Ауторка Роботић (Robotić, 2015) наводи да не постоји сагласност око термина, око етиологије зависности и око најбољег методолошког приступа. Такође, још увек не постоји сагласност око тога где су границе нормалног, односно прекомерног коришћења интернета. У литератури наилазимо на дефиницију зависности 
на интернету, која га одређује као „компулсивни нагон за претераним коришћењем интернетских услуга на начин који нарушава физичко и психичко здравље, те узрокује тешкоће у свакодневним породичном, социјалном и радном животу“" (Robotić, 2015: 84).

Они аутори који преферирају термин зависност од интернета сматрају да се ради о поремећају са озбиљним последицама по физичко и психичко здравље, као и по социјално, академско и радно функционисање. Истраживање које је рађено у Србији показује да су последице прекомерне употребе интернета бројне. На основу интервјуа са испитаницима аутори су открили да су преовладавајући симптоми физичке природе, као што су умор, исцрпљеност, недостатак сна, губитак апетита, болови у леђима и проблеми са видом, као и афективни, међу којима доминирају нервоза, безвољност, губитак интересовања за активности које немају директну везу са интернетом. Такође, особе које претерано користе интернет показују немар и неодговорност за свакодневне обавезе и социјално окружење (Hinić, 2008).

Поред великог броја истраживања у овој области у стручној литератури може се наћи мали број теоријских објашњења за етиологију компулсивне употребе интернета. Неки аутори (Davis, 2001; Griffiths, 2008; према: Vrućinić, Rodić, 2016) разликују специфичну и генерализовану патолошку употребу интернета. Специфична употреба односи се на претерано коришћење специфичних функција интернета и последица је психопатологије која је била присутна и раније. Генерализована патолошка употреба интернета укључује много времена на интернету без одређене сврхе и одлучујући фактор у њеном настанку јесте недостатак социјалне подршке и социјална изолација. Други аутори дају и теоријске поставке, за које су добили емпиријску потврду (Caplan, 2003; према: Vrućinić, Rodić, 2016: 69):
- особе које пате од психосоцијалних проблема (депресија и усамљеност) имају негативније перцепције о својим социјалним вештинама од особа које не пате од такве врсте тешкоћа;

- такве особе развијају склоност ка социјалним интеракцијама на интернету, због тога што их доживљавају мање претећим од непосредне комуникације „лицем у лице“;

- склоност ка социјалним интеракцијама на интернету води до претеране и компулсивне употребе интернета, која погоршава њихове проблеме и ствара додатне потешкоће на послу, школи и у породици.

Од етиолошких фактора у истраживањима најчешће се испитују особине личности, самопоштовање, присуство психичких сметњи, социјална подршка, породично функционисање. Када је у питању наша земља, истраживања која су се бавила испитивањем фактора ризика за појаву проблематичне употребе интернета су ретка (Vrućinić, Rodić, 2016).

Како постоје различити облици коришћења интернета (тражење информација, играње игрица на интернету, укључивање у „причаонице“ и размена порука, „виртуелни секс“, коцкање, трговина) зависност на интернету укључује неколико облика:

- информацијско йреойиерећене - компулсивно сурфовање интернетом или претраживање базе података, што доводи до смањене продуктивности рада и мање социјалне интеракције с пријатељима и породицом;

- мрежна комйулсивности - компулсивно играње игрица на интернету, коцкање, трговина или коришћење интернетских аукција; 


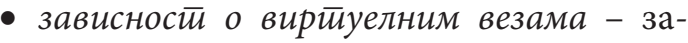
висност о друштвеним мрежама, причаоницама и порукама до тачке када виртуелни пријатељи постају важнији од стварног живота и односа са пријатељима и породицом;

- зависности о вирйуелном сексу - компулсивно коришћење интернетском порнографијом, причаоницама за одрасле и сличним страницама са негативним утицајима на интимне односе у стварном животу;

- зависности о комӣјуйеру - опсесивно играње компјутерских игрица или опсесивно програмирање (Robotić, 2015: 84).

Иста ауторка наводи да деца која имају мању контролу над коришћењем интернета имају лошију слику од себи, показују више симптома депресивности и склонија су неприхватљивом понашању. Зависност од интернетских игрица постаје све озбиљнији проблем у свету, као и дигитално насиље међу децом (енг. cyberbullying).

\section{Зависност од интернета и особине личности}

Прегледом релевантне литературе можемо уочити да постоје неке карактеристике које погодују развоју зависности. Тако Бугарски истиче да „понашање људи на интернету представља сложену интеракцију особина личности и неких битних карактеристика cyberspace-a“ (Bugarski, 2005; према: Radovanović, Spasić, 2009: 247). Ocновни начин комуникације је најчешће путем текста. Одсуство комуникације лицем у лице омогућава анонимност корисника који имају прилику да се представе у другачијем светлу, упознају велики број људи, истовремену комуникацију са више особа, једнак статус свих људи, превазилажење просторних ограничења и могућност чувања записа о искуствима на интернету. Креирање идентитета на интернету пружа корисни- цима могућност да конструишу свој идентитет у складу са својим жељама. Особе које пате од осећаја ниског самопоштовања, доживљаја личне неадекватности и неодобравања од стране других су под највећим ризиком да развију ову врсту зависности.

Ауторке Радовановић и Спасић (Radovanović, Spasić, 2009) наводе да су истраживања психолошких фактора зависности на интернету новијег датума и још увек не дају прецизну слику. Углавном, доминира утврђивање особина личности које доприносе зависности. Појам зависност од интернета први пут је описао амерички психијатар Иван Голдберг 1995. године. Од тада у свету, али и код нас, спроведена су истраживања која су имала за циљ утврђивање утицаја интернета на социјални живот и ментално здравље корисника. У стручним круговима, како наводе исте ауторке, још увек не постоји сагласност да ли ова појава заиста постоји или се ради само о лошој навици. Све то отежава проучавање повезаности употребе интернета са особинама личности, потребама и мотивима, психосоцијалним функционисањем и слично. Како постоје различити ставови, и резултати истраживања су различити, а понекад и контрадикторни. Крећу се од закључка о негативном деловању интернета на социјални живот и повезаности са неким особинама личности, преко ставова да интернет не доводи до смањења учествовања у реалном животу, до потпуног негирања било каквог утицаја и штетних последица.

Ауторка Роботић (Robotić, 2015) истиче да особе могу постати зависне од интернета због разних проблема са којима морају живети, а у посебном ризику су анксиозне и депресивне особе, особе које пате од других облика зависности, хиперактивне особе, особе са смањеном мобилношћу и друштвеном подршком, особе под стресом и слично. Ако је неки од ових модалитета посебно изражен, особа је подложнија развоју зависности од интернета због смањене 
способности суочавања са проблемима. Поменута ауторка истиче да је интернет некад само модалитет у коме се изражавају ове потешкоће и да често није технологија сама по себи та која изазива зависност. Због тога је веома битно да се будућа истраживања оријентишу на повезаност неких психичких проблема и поремећаја са развојем зависности од интернета. Лонгитудинална истраживања могу да открију како особине личности, породична динамика или интерперсоналне вештине могу да утичу на начин на који људи користе интернет.

Друге ауторке (Radovanović, Spasić, 2009) наводе да оно што је заједничко свим зависницима од интернета јесте чињеница да помоћу виртуелног света беже од реалних проблема, усамљености, проблема на послу, у школи, породици, лошег здравственог стања и слично. Истраживања зависности од интернета углавном су имала за циљ повезивање ове појаве са особинама личности. Најчешће су у фокусу следеће димензије (Radovanović, Spasić, 2009: 249):

- екстраверзија/интроверзија - дефинисана као степен индивидуалних социјалних интеракција насупрот повучености у себе и контроле понашања. Екстраверти су ведри, дружељубиви и активни, отворени и комуникативни, воле забаве и промене. Интроверти су повучени, тихи, резервисани у контакту са људима, стрпљиви, ретко се понашају агресивно.

- неуротицизам - дефинисан као општа емоционална лабилност, емоционална преосетљивост и склоност ка неуротским поремећајима.

- психотицизам - дефинисан као степен агресивног и импулсивног понашања и присуства аморалног система вредности и несентименталне оријентације у контакту са другима.
Осим ових димензија личности предмет интересовања истраживача су биле и друге карактеристике, начини психосоцијалног функционисања, социјална анксиозност, осећање усамљености и депресија и њихова повезаност са коришћењем појединих апликација и зависношћу од интернета уопште. Истраживачи са Универзитета у Амстердаму (Peter, Valkenburg \& Schouten, 2005; према: Radovanović, Spasić, 2009) анализирали су модел склапања онлајн пријатељстава адолесцената. Налази истраживања показали су повезаност психолошких карактеристика личности, мотива и образаца употребе интернета и њихов заједнички утицај. Утврђен је индиректан утицај димензија екстраверзија/ интроверзија на склапање пријатељстава на интернету. Он се остварује посредно преко спремности да се изнесу подаци о себи и фреквентности онлајн комуникације. Екстравертни адолесценти су показали већу спремност да износе интимне податке, али и интроверти су показали склоност ка овом виду комуникације. Ово понашање објашњено је мотивацијом да користе онлајн комуникацију као вид социјалне компензације за незадовољство комуникацијом лицем у лице. У нашој земљи спроведено је једно истраживање (Lelović, Damnjanović, Olujić, 2003; према: Radovanović, Spasić, 2009) ради утврђивања повезаности понашања везаног за интернет са интровертношћу и старошћу корисника. Зависност од интернета у овом истраживању већа је код жена, док су на друга два фактора (зависност од компјутера и заинтересованост за еротске садржаје на интернету) мушкарци остварили већи скор. Такође, утврдили су да екстраверзија негативно корелира са зависношћу од интернета. Односно, интровертне особе представљају ризичну групу за развијање зависности од интернета. Још једно истраживање спроведено код нас (Bodroža, Jovanović, Popov, 2008; према: Радовановић, Спасић, 2009) бавило се повезаношћу понашања људи у комуникацији на интернету са анксиозношћу. Утврдили су постојање 
пет димензија понашања: социјализација путем виртуелних друштвених заједница, зависност од њих, њихово компензаторно коришћење, виртуелни селф и негативан став према виртуелним заједницама. Истраживање је потврдило да постоји повезаност анксиозности са димензијом зависности и тенденција повезаности са компензаторним коришћењем. Према резултатима истраживања профила интернет зависника у Cpбији (Нinić, 2008), у којем је учествовало сто испитаника од шеснаест до педесет година, резултати су показали да популацију са симптомима интернет зависности чине подједнако мушкарци и жене, већим делом адолесценти и млађа популација, углавном средњошколци и студенти. Факторском анализом утврђене су три димензије патолошке употребе: мешовит тип са израженом потребом за актуелним информацијама, зависност од социјалне интеракције и потреба за забавом и стварањем хобија онлајн (сајберпорнографија, игрице, музика, уметност и слично). Оно што је заједничко за интернет зависнике јесте да се чешће баве интерактивним апликацијама на интернету, труде се да остваре доста социјалних односа на мрежи, а да им се при томе самопоуздање у реалном животу смањује, а социјална изолација и депресија увећавају.

\section{Карактеристике интернет генерације}

Савремено друштво пролази кроз револуцију информационих технологија. Старијим генерацијама ово је донело главобољу и отежало свакодневни рад, док млади, који су одрасли као део ове револуције, не могу замислити свакодневни живот и рад без помоћи технологије. Ову генерацију многи аутори називају нети $\overline{e н e-~}$ рацијом.

Последњих деценија аутори су смислили и друге називе као што су: нети іенераиије, іууіл іенерације, іенерације инсйанй йорука, мобилне іенерачије, ученици новоі миленијума и дру- ге. Поједини аутори истичу да између дигиталних урођеника и дигиталних имиграната (генерације рођене пре осамдесетих година 20. века, односно пре појаве дигиталних технологија) постоји дигитални јаз, који је последица разлика у њиховим дигиталним вештинама. Ово схватање многи сматрају неоснованим и штетним за дигиталне урођенике и из њега произилази да млади, самим тим што су рођени у дигиталној ери, поседују одговарајуће дигиталне вештине, а да су одрасли дигитално инфериорни у односу на своју децу. Нису сви дигитални урођеници подједнако дигитално писмени, већ и између њих постоје индивидуалне разлике, које се доводе у везу са социоекономским статусом, образовањем родитеља, школским постигнућем, математичком и читалачком писменошћy (Kuzmanović i sar., 2016).

У литератури нети іенерацију углавном дефинишу кроз седам заједничких особина:

- специфични;

- заштићени;

- самоуверени;

- оријентисани тимском раду;

- конвенционални;

- под притиском;

- успешни (Strauss \& Howe, 2006; према: Vidaković, 2013: 256).

Даље, у литератури се наводи да 20\% неши іенерације користи компјутер у узрасту између пет и осам година, а до своје шеснаесте готово сви. Изложеност информационим технологијама почиње веома рано, а свој врхунац достиже у адолесценцији. Могуће је учествовати у више од једне активности, што одражава тенденцију неш іенерације ка мултитаскингу. Ней іенерација развија неке специфичне обрасце понашања:

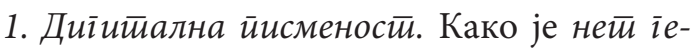
нерација одрасла у свету технолошке и информатичке револуције, они интуитивно користе све могуће технолошке 
погодности. Међутим, иако се осећају комотно при коришћењу технологије, њихово разумевање те технологије

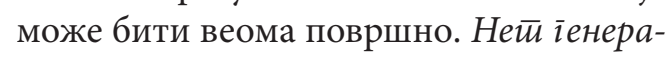
ција визуелно је писменија од претходних, те се многи од њих изражавају уз помоћ слика и визуелни видови комуникације им долазе природно.

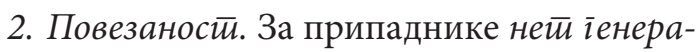
ције свет је одувек био добро умрежен, те они, више од било које друге генерације пре њих, искориштавају потенцијале друштвених медија. Иако су припадници нети іенерације увек у покрету, они су, уз помоћ технологије, стално умрежени.

3. Нейосреgности. Било да је упитању непосредност очекиваног одговора или брзина којом су навикли да примају информације, припадници нети іенерачије су брзи. Они раде више ствари истовремено (мулииитаскују), брзо прелазе са једне активности на другу. Имају брзо време одговора, било да играју игрице или разговарају путем инстант порука. Може се рећи да се код њих чак и више важности ставља на брзину него на тачност.

4. Искустиво. Већи део нети іенерације радије учи путем делања него путем инструкција. Они уче кроз откривање - личним истраживањем или у комуникацији са својим вршњацима. Овакав вид учења им омогућава да боље усвоје нове информације и да их после користе на креативне и значајне начине, односно карактеристике које ове ученике и студенте одвајају од свих претходних генерација.

5. Дружељьуивости. Ови ученици имају отворен став према непознатом и различитом од онога на шта су навикли.
Велики број њихових интеракција на интернету је емотивно отворене природе, те немају проблем да деле потпуно личне информације о себи. Ней іенерација је развила одређени механизам укључивања људи у групе, која не зависи од тога да ли неку особу знају лично или само кроз виртуелну групу (Vidaković, 2013: 259).

\section{Медијска писменост и подизање свести о ризицима на интернету}

Медији су ушли у наше домове и постали саставни део живота. Истраживања широм света показују да људи проводе све више времена користећи различите медије. За данашњу нет генерацију медији су постали примаран фактор социјализације. Ружић (Ružić, 2013) наводи да се медијска писменост од шездесетих година пропагира као вештина које ће заштитити публику од манипулације.

Ауторка Зграбљић Ротар (Zgrabljić Rotar, 2005) истиче једну од дефиниција медијске писмености, која је дата на Конференцији о медијској писмености 1992. године, и одређује је као способност приступа, анализе, вредновања и одашиљања порука посредством медија. Унеско је још седамдесетих година прошлог века покренуо питање образовања за медије. Лин Мастерман (према: Gone, 1998: 22) наводи седам разлога за медијско образовање:

- висока потрошња медија и презасићеност до које стижемо;

- идеолошки значај медија, посебно имајући у виду рекламе;

- појава информационог руковођење у предузећима;

- нарастајући продор медија у демократским процесима; 
- нарастајући значај визуелне и информационе комуникације у свим доменима;

- очекивања младих да буду образовани тако да могу да разумеју своје доба;

- национални и међународни пораст приватизације свих информационих технологија.

Због огромне количине информација на интернету људи мисле да су информисани. Међутим, многи упозоравају да интернет није медиј коме се може безусловно веровати. Интернет је канал за дистрибуцију информација, тако да тамо свако може да пласира полуистине. Захваљујући интернету свет је постао глобално село (Vidaković, 2013).

Други аутори (Starčević, 2013) истичу да нас медији обавештавају и забављају, али истовремено говоре шта је добро, а шта лоше. Својим моћима да побуде осећања код деце, да их убеде, као и простором које заузимају у слободном времену прете да озбиљно угрозе породицу и школу на пољу усмеравања социјалног понашања. Интернет нуди разноврсне информације, али информисаност се не може назвати знањем. Информација постаје знање тек када се може проверити и доказати. Образоване за меgије, медијско образоване, медијска иисменосй синоними су који се користе за програме који се спроводе већ годинама у многим земљама и чији је циљ да оспособе децу за критички приступ порукама добијеним од стране медија. Како деца проводе велики део слободног времена на интернету и имају приступ различитим садржајима, медијско образовање постаје веома значајно. Медијску писменост многи аутори схватају као крајњи циљ медијског образовања. Суштина медијске писмености обухвата: 1) упознавање медија; 2) упознавање са ризицима које медији носе; 3 ) препознавање могућности медија - образовних, културних и информативних и 4) развијање критичког и одговорног односа према медијским садржајима (Starčević, 2013: 225). Та- кође, у Сӣрайеīији систиема јавноі информисана у Рейублици Србији gо 2016. іолине наглашава се потреба за подизањем нивоа медијске писмености. Суштина медијске писмености је да кориснике упозна са ризицима које носе медији, али и са њиховим могућностима.

У данашње време, како смо већ споменули, свако може објављивати на интернету, а деца углавном верују свему што прочитају. Интернет је препун тачних информација, али и оних које су нетачне. Ауторка Роботић (Robotić, 2015) истиче да није довољно само знати како се служити интернетом, већ знати и проматрати медије на критичан начин. Такође, истиче се улога родитеља, школе, локалне заједнице, као и медија у заштити деце на интернету. Потребно је знати какви ризици постоје на интернету и како њима управљати. Међутим, родитељи се често осећају немоћно када њихово дете зна више о интернету од њих. Безбедност деце на интернету не зависи само од њих, већ и од свих људи који се служе интернетом. Поред родитеља, поменута ауторка сматра значајном и улогу школе и наставника, који проводе доста времена са децом. То им пружа могућност да упознају децу са опасностима на интернету и начинима заштите. Да ли ће бити штете од коришћења интернета не зависи само од времена проведеног на интернету, већ у које сврхе га дете користи. Како би заштитили децу, поменута ауторка сматра да родитељи треба да добро познају децу, успоставе са њима топао и отворен однос у којем ће деца бити спремна да комуницирају слободно, чак и о најосетљивијим стварима. Родитељи који немају довољно знања о новим технологијама требало би да се упознају са њима да би могли надзирати дететов приступ интернету. Важно је да не претерају у ограничавању употребе интернета, који има и своје предности. 


\section{Превенција зависности од интернета и заштита деце и младих на интернету}

Прегледом релевантне литературе можемо закључити да интернет има своје добре и лоше стране, а као свака заједница, добре и лоше чланове. Као и у стварном свету увек ће бити криминалних људи, који ће на неки начин покушати да злоупотребе нове технологије. Због тога је потребно те ризике проценити и наћи начине да се њима управља. Ауторка Роботић (Robotić, 2015) истиче да интернет посебно представља опасност за децу и младе који често претражују овај медији и тако долазе до садржаја који нису примерени њиховом узрасту и степену развоја. У заштити деце на интернету велику улогу имају родитељи. Они не би смели, имајући поверење у децу, да препусте коришћење интернета само у њихове руке. За лоше ствари које се дешавају на интернету, заправо, није крив интернет већ људи који га злоупотребљавају. Осим што користе интернет за забаву, родитељи морају да науче децу да интернет користе и за учење. Превише проведеног времена за компјутером и на интернету доводи до различитих проблема као што су: „повећана агресивност, смањена физичка активност, несаница, неуспех у школи, смањење комуникације у породици и смањена пажња и интерес“ (Robotić, 2015: 92).

Иста ауторка истиче да децу и младе треба упозорити да на интернету заштите своје личне податке. Такође, треба им нагласити да још увек не постоји начин да се уклони садржај који је неко поставио на интернет. На интернету постоји много страница које пружају корисне информације о томе како разговарати са децом о опасностима интернета. Заштита деце на интернету и превенција зависности захтева сарадњу целе локалне заједнице и друштва, не само родитеља, школе, полиције, служби за заштиту. Едукацијске кампање, које су намењене не само деци, родитељима, стручњацима већ свим осо- бама, једини су начин осигуравања примерене заштите и превенцијског начина размишљања, према речима исте ауторке (Robotić, 2015). Такође, детету су потребни надзор и контрола али је неопходно и упућивање на правила за коришћење и употребу интернета и друштвених мрежа (Rajić, 2012: 73).

Велику улогу у заштити деце на интернету треба да имају и медији, који треба да подстичу едукацију јавности о тим питањима ширећи одговарајуће информације. Зато је веома важан педагошки однос према медијима, односно медијско образовање. Овде се, опет, истиче важност медијске писмености. Деца данас проводе велики део времена на интернету, који уз многе позитивне стране носи и одређену количину штетних садржаја. Не треба им забрањивати овај медиј. Једина заштита је едукација деце, уз добар узор и надзор (Robotić, 2015).

Хинић (Hinić, 2008) истиче да за већину људи интернет не представља неопходну потребу и његово коришћење не одузима време од осталих офлајн обавеза. Задатак за истраживаче јесте да са озбиљношћу приђу пројекту стандардизације неке од тренутно коришћених скала интернет зависности, јер постоји страх да ће улазак наше земље у европске и светске токове довести до пораста броја особа са симптомима зависности од интернета. Исти аутор наводи да су најугроженији деца и млади чије је психолошко формирање још у току и као такво може бити озбиљно измењено прекомерном употребом било којег облика информационе технологије, па и интернета.

\section{Закључак}

Последњих година примећује се повећано интересовање за ову тематику, не само у свету него и код нас. Данас је уобичајено да деца почињу да користе интернет од најранијег узраста. Са порастом коришћења интернета расте и ри- 
зик од потенцијалне изложености деце различитим непримереним садржајима, злоупотребама и искоришћавању.

Анализом релевантне литературе можемо закључити да интернет има своје добре и лоше стране. Као и свака друга заједница може имати своје добре и лоше чланове. Као и у стварном свету увек ће бити криминалних људи, који ће на неки начин покушати да злоупотребе нове технологије. Како је интернет постао део свакодневног живота, потребно је те ризике проценити и наћи начине да се њима управља. Умногоме је олакшао начине на које људи комуницирају, уче, раде. Предности интернета за учење и развој огледају се кроз развој важне интелектуалне компетенције, једноставније долажење до информација, формирање ставова и вредности о интересима и активностима које их повезују, брзу и лаку комуникацију, занимљивији начин учења, као и подстицање креативности. Младима се пружа могућност да похађају академије еучења (енг. e-learning academy), као и онлајн образовање. Међутим, и поред његових предности постоје и потенцијални ризици, којима су нарочито подложни деца и млади, јер често долазе до садржаја који нису примерени њиховом узрасту и степену развоја. Како се повећава време које корисници проводе на интернету, расту и ризици и изложеност деце различитим садржајима. Свако може објављивати на интернету у данашње време, самим тим препун је информација које су тачне, али и оних које су нетачне. Да ли ће и колико бити штете од коришћења интернета не зависи само од времена проведеног на интернету, већ и у које сврхе се користи. Није довољно само знати како се служи интернетом, већ и проматрати медије на критичан начин. Због тога се истиче значај медијске писмености. Такође, веома је важна улога родитеља, школе, локалне заједнице, као и медија у заштити деце на интернету. Заштита деце на интернету и превенција зависности захтева сарадњу целе локалне заједнице и друштва, не само родитеља, школе, полиције, служби за заштиту. Један од начина осигуравања заштите и превенције јесу и едукацијске кампање, које су намењене не само деци, родитељима, стручњацима већ свим особама. Деца проводе велики део слободног времена на интернету, који уз многе позитивне стране поседује и одређену количину штетних садржаја. Jeдина заштита је едукација деце, уз добар узор и надзор.

Бројна истраживања која се спроводе имају за циљ утврђивање утицаја интернета на социјални живот и ментално здравље корисника. Како још увек не постоји сагласност да ли ова појава заиста постоји или се ради само о лошој навици, све то отежава проучавање повезаности употребе интернета са особинама личности, потребама и мотивима, психосоцијалним функционисањем и слично. Резултати истраживања су различити и често контрадикторни, јер постоје различити ставови који се крећу од закључака о негативном деловању интернета и повезаности са неким особинама личности до негирања било каквог штетног утицаја.

\section{Литература}

- Andevski, M., Vidaković, M., Arsenijević, O. (2014). Internet u nastavi i učenju. Posećeno 10.02.2018. na www: http:// portal.sinteza.singidunum.ac.rs.

- Gone, Ž. (1998). Obrazovanje i mediji. Beograd: CLIO.

- Hinić, D. (2008). Korisnički profili internet zavisnika u Srbiji. Psihologija. 41 (4), 435-453. Posećeno 27.02.2018. na www: http://scindeks-clanci.ceon.rs/data/pdf/0048-5705/2008/0048-57050804435H.pdf . 
- Kovačević-Lepojević, M. (2011). Pojam i karakteristike internet-zavisnosti. Specijalna edukacija i rehabilitacija. 10 (4), 615-631. Posećeno 3.03.2018. na www: http://www.casopis.fasper.bg.ac.rs/izdanja/SEIR2011/ vol10br4/1Spec_Edu_i_Reh_ISTRAZIVANJA/4-Marina_Kovacevic_Lepojevic.pdf.

- Kuzmanović, D., Lajović, B., Grujuć, S., Medenica, G. (2016). Digitalno nasilje - prevencija i reagovanje. Beograd: Ministarstvo prosvete, nauke i tehnološkog razvoja - Pedagoško društvo Srbije.

- Mojović, V. (2012/2013). Značaj i primena interneta u obrazovanju u osnovnoj školi. Posećeno 21.02.2018. na www: http://www.ftn.kg.ac.rs.

- Popadić, D., Kuzmanović, D. (2016). Mladi u svetu interneta: korišćenje digitalne tehnologije, rizici $i$ zastupljenost digitalnog nasilja među učenicima u Srbiji. Beograd: Ministarstvo prosvete, nauke i tehnološkog razvoja. Posećeno 15.02. 2018. na www:http://www.mpn.gov.rs/wp-content/uploads/2015/08/Mladi_u_svetu_interneta_web.pdf.

- Popović, M. (2016). Internet i mladi (master rad). Niš: Univerzitet u Nišu.

- Radovanović, I., Spasić, D. (2009). Osobine ličnosti i internet zavisnost. U: Radovanović, D. (prir.). Istraživanja u specijalnoj pedagogiji (243-255). Beograd: Fakultet za specijalnu edukaciju i rehabilitaciju.

- Rajić, S. (2012). Bezbednost dece na internetu i društvenim mrežama. Inovacije u nastavi. XXV (2), 69-79.

- Robotić, P. (2015). Zamke virtualnog svijeta: zaštita djece i mladih na internetu i prevencija ovisnosti. JAHS. 1 (2), 81-96. Posećeno 5.03.2018. na www: http://www.hrcak.srce.hr/file/240160.

- Ružić, N. (2013). Medijska pismenost kao način zaštite od manipulacije. U: Valić Nedeljković, D., Pralica, D. (ur.). Digitalne medijske tehnologije i društveno-obrazovne promene 3 (209-215). Novi Sad: Filozofski fakultet, Odsek za medijske studije.

- Starčević, N. (2013). Medijsko obrazovanje - putokaz u svetu zaštićenom medijima. U: Valić Nedeljković, D., Pralica, D. (ur.). Digitalne medijske tehnologije i društveno-obrazovne promene 3 (217-227). Novi Sad: Filozofski fakultet, Odsek za medijske studije.

- UNICEF (2016). Istraživanje o nivou svesti o potencijalnim rizicima i zloupotrebama među roditeljima dece uzrasta 8 do 17 godina. Posećeno 5.03.2018. na www: http://www.unicef.rs/files/Istrazivanje\%20o\%20 nivou\%20svesti\%20roditelja\%20o\%20rizicima\%20od\%20zloupotrebe\%20dece\%20na\%20internetu.pdf.

- Vidaković, M. (2013). Net generacija i e-učenje: Savremena obrazovna revolucija. U: Valić Nedeljković, D., Pralica, D., (ur.). Digitalne medijske tehnologije i društveno-obrazovne promene 3 (255-265). Novi Sad: Filozofski fakultet, Odsek za medijske studije.

- Vrućinić, Ž., Rodić, M. (2016). Povezanost vaspitnih dimenzija i problematične upotrebe interneta kod mlađih adolescenata. Defendologija. 19 (37-38), 63-80.

- Zgrabljić Rotar, N. (2005). Mediji - medijska pismenost, medijski sadržaji i medijski uticaji. U: Zgrabljić Rotar, N. (ur.). Medijska pismenost i civilno društvo (1-15) Sarajevo: MediaCentar.

- Zluković, S., Slijepčević, S. (2015). Roditeljska kontrola ponašanja dece na internetu i socijalnim mrežama. Nastava i vaspitanje. 64 (2), 239-254. 


\begin{abstract}
Summary
Nowadays, it is common for information and communication technologies to be available to children at the youngest age. The results of the research conducted globally and in our country indicate that there is an increase in the number of Internet users. The widespread use of the Internet began in the 90s of the previous century and very quickly turned into an enormous pool of information, the new ways of communication, social networks, and the like. As with any other medium, the Internet has so far influenced the changing of life-styles and the ways of communication. The advantages of the Internet for learning and development are reflected in the development of important intellectual competences, an easier access to information, the formation of attitudes and values about the interests and activities that connect them, a quick and easy communication, a more interesting way of learning, and in encouraging creativity. Young people are given an opportunity to attend e-learning academies, and they also have access to online education. However, with the increased and uncontrolled use of the Internet, the risk of the potential exposure of young people to various inappropriate contents, abuse and exploitation is also increasing. The more time children spend on the Internet, the higher the risk of their exposure to various contents that they are especially susceptible to, and that are often inappropriate for children's age and their level of development. The extent of the harm caused by using the Internet, or whether there will be no harm at all, depends not only on the time spent on the Internet, but also on what it is used for. The aim of this paper is to look at the potential risks of using the Internet and the possibilities of preventing Internet addiction based on the review and analysis of the relevant literature. The concept of Internet addiction came into being in the 90s of the previous century, but there is still no agreement regarding the recognition of this concept, term and etiology, nor about the best methodological approach to it. As information and communication technologies are a part of our everyday life, the role of parents, pedagogues, teachers, and the entire community becomes more complex.
\end{abstract}

Keywords: advantages and risks of using the Internet, Internet addiction, prevention, young population, media literacy. 